\title{
SKILlS, ADMINISTRATION AND AGE MANAGEMENT: A CALL FOR INSTITUTIONAL ARRANGEMENTS FOR NEW MIGRANTS ARRIVING IN EUROPE
}

\begin{abstract}
Migration to the European Union from African and Asian countries are one of the key issues of the political and economic agenda of the second decade in the $21^{\text {st }}$ century. This paper studies the proposals concerning tools in the scope of skills, administration and age management, which will grant to newcomers the appropriate incentives needed for action. Erroneous institutions may lead to misguided incentives, rent seeking and migrants chasing unproductive activities, which in turn does not lead to the construction of a market economy. We posit that migration into Europe should be subject to programmes coordinated at the European level. Military action cannot stop the infiltration of millions more, which in turn means that managing the new arrivals should be coordinated at the EU level, and the tools of administration, skills management and age management should be actively used in selecting, including into the labour market and activating the job potential of migrants.
\end{abstract}

KEYWORDS: migration, Europe, demography, age management, skills, administration management, immigration, policy

\section{INTRODUCTION}

the contemporary world and the changes we are seeing have led us to redefine many phenomena and their analysis in the context of current politics. One of these phenomena is migration bound for Europe, although we do 
need to disclaim that this phenomenon has already been extensively studied in the past (Cesarani, Fulbrook, 2002; Lavenex, Uçarer, 2003; Pojmann, 2008; Thränhardt, 1992; Zincone et al., 2011). Europe has a long-standing tradition of humanism and universalism, which in turn exert pressure on the formal and informal institutions of its societies. Naturally there are also bases for the opposite views, albeit it has been humanism and universalism that have dominated Christian worldviews, wherein all people are created equal and their dignity is equally important. However, relevant elements of European thought, such as the ideals of freedom, i.e. liberalism, are in fact part of a European philosophy, but do not necessarily make up the core of worldviews shared by other civilizations from non-occidental cultures. This leads to misunderstandings, conflicts and pressures, at a time when Europeans and non-EU migrants interact more than ever before. This paper shall analyse the actions, in terms of skills, administration and age management aimed at migrants, that will help assimilates them and incorporate them into the European economy.

\section{THE IMPORTANCE OF MIGRATION AND ITS MAIN TRENDS}

The subject of mass migration into the EU has become a key issue in Europe. Public opinion is very divided on this matter, so too is the political class. A significant part of society fears an invasion of foreign cultures, religions that are allegedly hostile towards Western values, while others rate migrants in a more positive framework, seeing in them the opportunity for continued development of European values, within the framework of multicultural Europe (Armbruster, Meinhof, 2011, Council of Europe, 2006; Tausch, 2008). Thanks to its recognition of the right to multiculturalism this movement in Europe is against „cultural imperialism”, wherein part of the public discourse contains perspectives that are far away from the mainstream. Nonetheless, migration is still a considerable issue facing Europe. Figure 1 shows the most important subjects for Europeans in 2015. 
Figure 1.

Most important challenges facing the EU in 2015

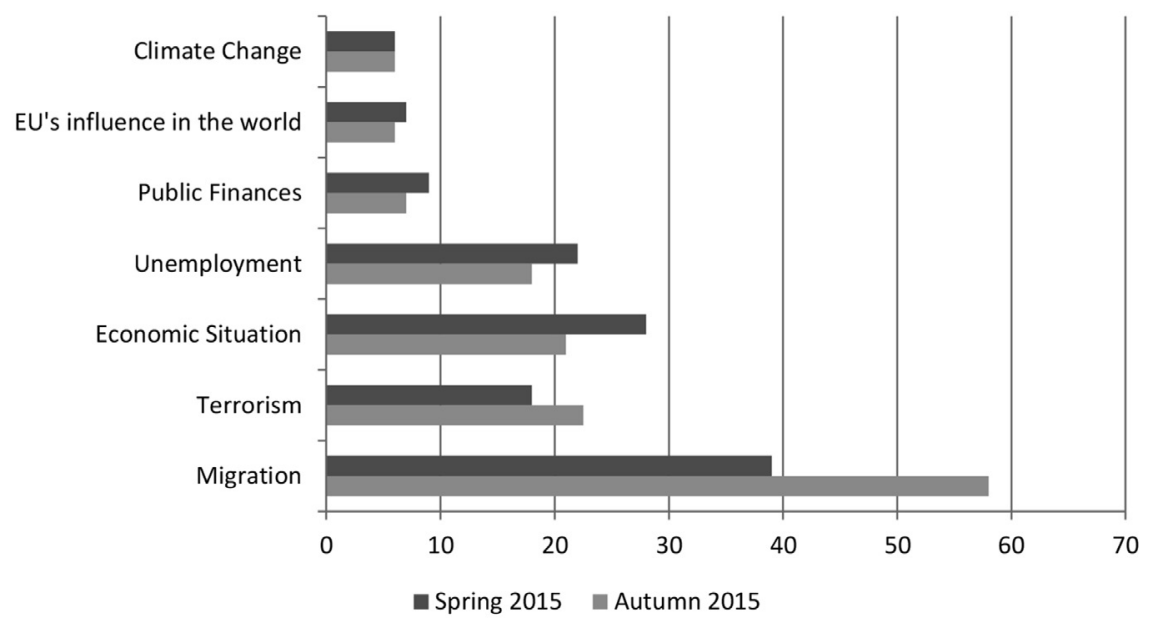

Source: Eurobarometer (2015)

Migration is influenced by multiple economic, political and social factors. The causes and factors influencing migration can be found in the Lee model (1966, p. 47-57), and can be divided into the country of origin of the migrant (push factors) and those from the target country (pull factors). People migrate from places with less opportunities, lower wages, low quality of life, to places with significantly higher indices. In reality the wage disparity is a manifestation of the unfulfilled potential of the world economy, which would be activated only in a world of borderless exchange. According to the studies conducted by Michael Clemens, a border-free world would lead to the doubling of global GDP (Clemens, 2011; Clemens, 2013). The effect in turn would be much higher world production. The arrival of newcomers is akin to melt water in the spring, which powers the water mill in a quicker way, thus producing more energy. More tax paid by a larger number of workers means more funds for education, roads and infrastructure, increasing the efficiency and productivity of society as a whole.

Nevertheless negative response of immigration is based on the assumption that migrants are a burden and cost to a destination country (Cohen, Sirkeci, 2011, p. 99). Response varies depending on region of the Europe. East Europe 
society is more hostile to foraigners compared to West Europe (Halpern, 2010). According to Spring Global Attitudes survey (2014) 86\% people from Greece, 80\% from Italy, 57\% from France, 54\% from UK, 47\% from Spain, 44\% from Germany, $40 \%$ Poles is saying their county should allow fewer immigrants to accept. It's is even more striking compared to opinions about immigrants (figure 2.).

Figure 2.

Opinions about migrants based on survey

Immigrants today are a burden on our country because they take our jobs and social benefits

\begin{tabular}{|c|c|c|}
\hline Greece & 70\% |||| & $51 \%$ \\
\hline Italy & $69 \% \quad|| \mid$ & $45 \%$ \\
\hline France & $52 \% \quad\|\| \| \mid$ & $36 \% \quad|||||||||||||| \mid$ \\
\hline Poland & $52 \% \quad\|\|\|\| \|$ & 21\% |||||||||||||||||||||| \\
\hline Spain & $46 \% \quad\|\| \| \mid$ & 25\% |||||||||||||||||||||||||| \\
\hline UK & $37 \% \quad\|\|\|\|$ & $20 \%$ \\
\hline Germany & $29 \% \quad||||||$ & $48 \%$ \\
\hline
\end{tabular}

Source: Spring Global Attitudes survey, 2014.

As opposed to popular wisdom new migrants do not take jobs away from host country citizens. Migrants, who usually hail from lower-income societies, are ready to work in jobs unattractive to locals. They have different and complementary skills in terms of what is offered locally, which is also another finding of studies on the subject ${ }^{1}$. If migrants were to steal jobs, the same would be true for each graduate leaving college and entering the labour market. In reality the opposite is true, as the economy expands, and the aggregate number of jobs available is increased, akin to the growth of a living organism. Today's worker is a potential entrepreneur tomorrow. Migration awakens economic forces that raise real wages in the entire economy and create pressure towards more education. Thus each member of society can benefit from the arrival of migrants and migration is the most efficient and largest programme of combating poverty ever known to man. Evidence of this can be found in the remittances from rich to poor countries. Figure 3 shows that unemployment of immigrants is only slightly higher than native-born. 
Figure 3.

Unemployment rates of foreign-born compared to native-born

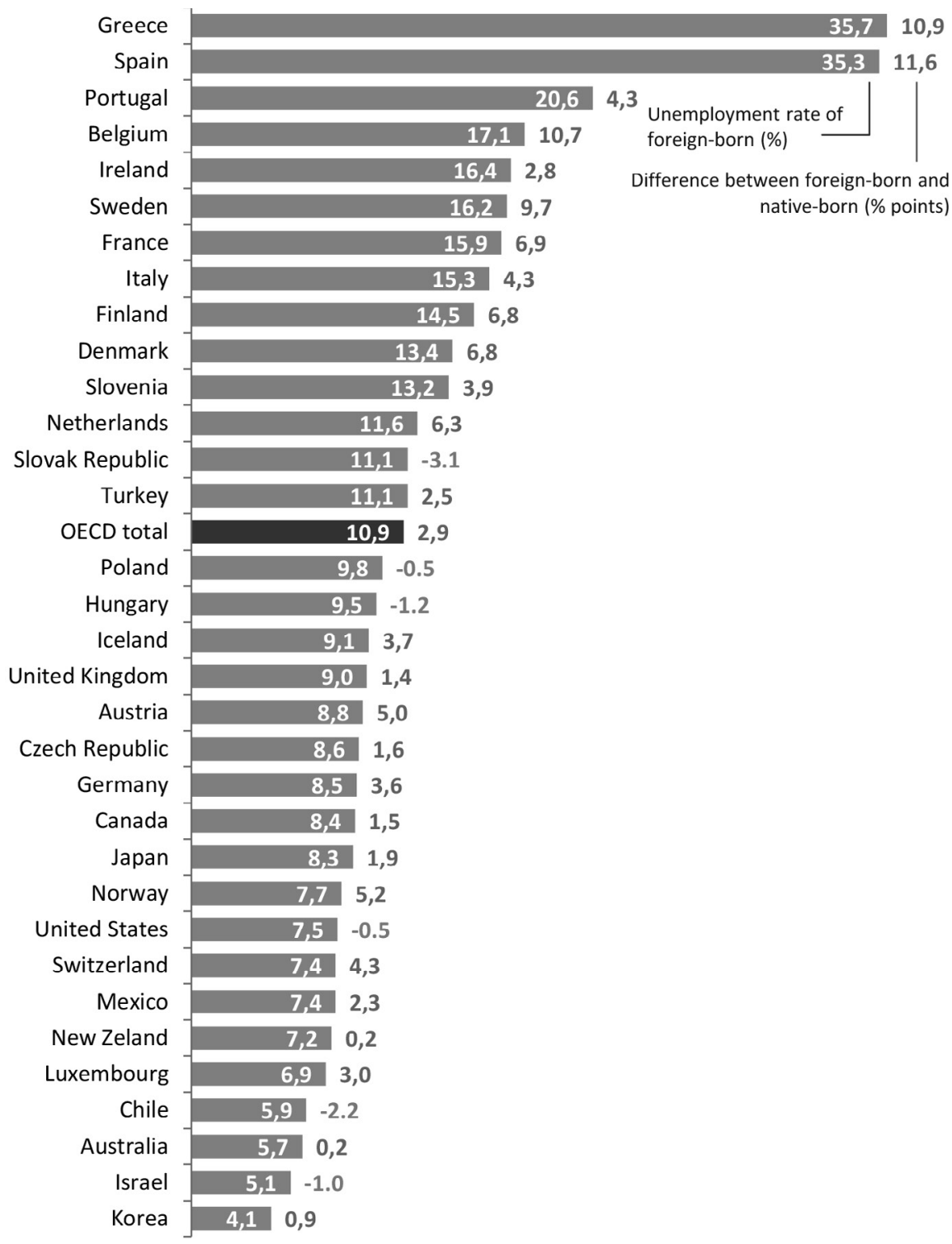

Note: Dataset based on 2012-2013 study

Source: OECD database, based on “Indicators of Immigrant Integration" study, 2015 


\section{The ECONOMIC DISCUSSION ON MIGRATION}

Economic theories do not undermine the significance of demographics and human capital for the economy. For the EU migration is beneficial, as it guarantees the adequate allocation of resources, providing cheaper and more efficient labour, in turn boosting production and prosperity in the host country. The beneficial effects of migration in the host countries include demographic changes leading to a sustained/increasing population and stopping the ageing of populations through the net inward migration of young people, together with the possibility of harnessing the knowledge and experience of the migrants. Looking at migration through the lens of labour demand and supply, we can see that migration means a net increase in labour and the rise in the range and diversity of services and wages. Immigrants lower the price of many relatively simple services, which were conducted hitherto by relatively high-skills workers in their free time, who sometimes even had to forego paid work altogether, e.g. cleaning or caring for the elderly or children - thanks to migrates the return of highly-qualified women to the labour market is possible right after childbirth. In effect the economy's productivity rises. Newcomers do not seek high wages, which leads to lower production costs, and thus to dropping prices for goods and services. And when prices drop, demand increases - be it internal and external, due to the increased price competitiveness of exports. And these are not the only benefits. A larger population diminishes the relative price of public goods - public education, the army and bureaucracy. The host country loses out in the balance of payments, as part of the funds are remitted to countries of origins.

Adam Smith said that specialisation and the division of labour are essential to economic growth (Smith, 1954). Migration is a further supporter of these as it provides more labour, where it is needed and where it will be used most efficiently. Migration carries with it the untapped potential if and when migrants will have the right incentives to work and not rely on welfare. The newcomers are not helped by the fact that they oftentimes hail from countries where the authorities hamper entrepreneurship and promote religious or social intolerance or discrimination based on one's gender or views. Involuntarily, part of this reality, in the shape of formal and informal institutions, is carried over to their host countries. The role of host country 
governments is to shape institutions and incentives in a way that leads newcomers to start working and not cultivate bad role models carried over from their homelands. This begs the question as to what type of migrants does Europe accept and what is the shape of the institutions that influence new EU migrants.

\section{EUROPEAN DEMOGRAPHY IN CRISIS. MIGRATION AS A SOLUTION}

The total number of people deciding to migrate has only slightly changed in relation to total world population, however it does seem that in recent years this phenomenon has become more relevant. Specifically in Europe, where institutions make up the system known as the European Social Model, with large social outlays, a large role of the state in the economy, and low fertility rates of the member states (Prokurat, 2010). UE has a system of welfare entitlements, which is one of the most important reasons that Europe is attracting so many immigrants (Prokurat, 2011). Faced with low levels of population growth and the linked phenomenon of population ageing, the role of international migration in shaping the state and structure of societies is greatly increased. Very high levels of immigration are projected for the years ahead in Europe.

Demographic analyses show that not only European but worldwide fertility rates are plummeting, while at the local level, and on great areas of the globe, populations are experiencing zero or negative growth (Bongaarts, 2009 , p. 2985-2990). In 1985 to 1990 world fertility rate averaged 3.4 children per woman. In 1996 this number felled to 3.0 and in 2006 droped 2.8 (Jones, Lopez, 2006). In many countries fertility rate in below replacement value (2.1 children). From the 1980s in almost all European Union member states there is statistically less than two children per woman in her reproductive age. The current level of demographic growth thus does not guarantee the biological maintenance of European societies. Demographic prognostics together with the structure and needs of the European economy suggest that in order to maintain the current level of socio-economic development, by 2050 Europe must have attracted around 150 million migrants, with their proportion attains levels as high as $20 \%$ of their host populations (Kamusella, 2003, p. 42-45). 
Figure 4.

Summary of data regarding migrants in UE in 2015

\begin{tabular}{|c|c|c|c|}
\hline UE country & $\begin{array}{l}\text { Total amount } \\
\text { of migrants }\end{array}$ & $\begin{array}{l}\text { Immigrants from } \\
\text { outside of EU }\end{array}$ & $\begin{array}{c}\text { Migrants as a } \% \\
\text { of society }\end{array}$ \\
\hline Austria & $1057 \mathrm{k}$ & $539 \mathrm{k}$ & $12,4 \%$ \\
\hline Belgium & $1264 \mathrm{k}$ & $434 \mathrm{k}$ & $11,3 \%$ \\
\hline Bulgaria & $45 \mathrm{k}$ & $41 \mathrm{k}$ & $0,8 \%$ \\
\hline Croatia & $32 \mathrm{k}$ & $21 \mathrm{k}$ & $0,7 \%$ \\
\hline Cyprus & $159 \mathrm{k}$ & $48 \mathrm{k}$ & $18,6 \%$ \\
\hline Czech Rep. & $434 \mathrm{k}$ & $261 \mathrm{k}$ & $4,1 \%$ \\
\hline Denmark & $397 \mathrm{k}$ & $233 \mathrm{k}$ & $7,1 \%$ \\
\hline Estonia & $195 \mathrm{k}$ & $187 \mathrm{k}$ & $14,8 \%$ \\
\hline Finland & $207 \mathrm{k}$ & $122 \mathrm{k}$ & $3,8 \%$ \\
\hline France & $4157 \mathrm{k}$ & $2706 \mathrm{k}$ & $6,3 \%$ \\
\hline Germany & $7011 \mathrm{k}$ & $3912 k$ & $8,7 \%$ \\
\hline Great Britain & $5047 \mathrm{k}$ & $2424 \mathrm{k}$ & $7,8 \%$ \\
\hline Greece & $837 \mathrm{k}$ & $649 \mathrm{k}$ & $7,7 \%$ \\
\hline Hungary & $140 \mathrm{k}$ & $59 \mathrm{k}$ & $1,4 \%$ \\
\hline Ireland & $545 \mathrm{k}$ & $171 \mathrm{k}$ & $11,8 \%$ \\
\hline Italy & $4922 \mathrm{k}$ & $3480 \mathrm{k}$ & $8,1 \%$ \\
\hline Latvia & $305 \mathrm{k}$ & $299 \mathrm{k}$ & $15,2 \%$ \\
\hline Lithuania & $21 \mathrm{k}$ & $16 \mathrm{k}$ & $0,7 \%$ \\
\hline Luxembourg & $249 \mathrm{k}$ & $34 \mathrm{k}$ & $45,3 \%$ \\
\hline Malta & $25 \mathrm{k}$ & $11 \mathrm{k}$ & $5,9 \%$ \\
\hline Netherlands & $735 \mathrm{k}$ & $330 \mathrm{k}$ & $4,4 \%$ \\
\hline Poland & $101 \mathrm{k}$ & $71 \mathrm{k}$ & $0,3 \%$ \\
\hline Portugal & $401 \mathrm{k}$ & $301 \mathrm{k}$ & $3,8 \%$ \\
\hline Romania & $73 \mathrm{k}$ & $52 \mathrm{k}$ & $0,4 \%$ \\
\hline Slovakia & $59 \mathrm{k}$ & $12 \mathrm{k}$ & $1,1 \%$ \\
\hline Slovenia & $97 \mathrm{k}$ & $80 \mathrm{k}$ & $4,7 \%$ \\
\hline Spain & $4677 \mathrm{k}$ & $2685 \mathrm{k}$ & $10,1 \%$ \\
\hline Sweden & $687 \mathrm{k}$ & $385 \mathrm{k}$ & $7,1 \%$ \\
\hline
\end{tabular}

Source: data based on Eurostat (2015). 
The demographic crisis leads to accelerated population ageing. People over 50 make up over a third of the EU's population. In terms of individual countries the situation is even more drastic. According to estimates by the UN and Council of Europe, as early as 2030-2035 Germany and Italy will see these age brackets making up as much as $40 \%$ (European Commission, 2002). Currently there are many European countries feeling the lack of workers. Furthermore, the proportion of working age to retired persons are changing for the worse. Currently the European average is three economically active people for one retired person and according to Eurostat it will be one and half active for one retired in 2030. The proportion of people of working age in the EU-28 is shrinking while the relative number of those retired is expanding (Eurostat, 2016). Thus the contemporary social security model will be impossible to sustain. Also the healthcare and social sectors are facing collapse. Mathers et al. show that life expectancy has risen on par with the general health of populations, which in turn permits a longer working career to offset longevity (Mathers et al., 2001, p. 1685-1691). Therefore, while life expectancy has increased, the period at the end of life, where individuals only consume and do not generate income, has remained stable. According to Eurostat, by 2025 the number of working age people in the EU will shrink by 52 million. Taking into consideration population ageing (figure 3 ) it's clear that Europe has to find a remedy for that challenge.

Ageing populations suffer three kinds of deficits. First of all they witness a shortage of benefits. The second problem is the diminished creativity of a society. Thirdly the savings rate plummets, as the elderly spend their life's savings. Thus EU acceptance of immigration and legal employment of workers from outside the EU will become the remedy for this ageing problem. Therefore it is essential to regulate this issue at the European level.

In 2015 situation is tense as European Union received 832.000 migrants via the Mediterranean Sea. That is four times more than in 2014, when over 200.000 arrived $^{1}$. Not all rich countries, including European Union members, are interested in accepting all groups of migrants. Some countries focus on highly skilled workers and try to prevent unskilled migrant labour to enter 
thir market. Nevertheless, last decade has seen the flourishing of illegal people smuggling in into the EU, dominated by organised crime mainly from Southern and Eastern Europe. According to the International Office on Migration, most migrants crossed the EU border in Spain, Greece and Italy and came to the EU from war zones such as Syria, Eritrea and Afghanistan. Others hail from Libya, Sudan, Pakistan, Nigeria, Somalia and Iraq. Thus it is very important to monitor these migration flows by and foster monitoring and control actions, while putting into force policies that include immigrants management in order for them to benefit all parties.

Figure 5.

Population ageing in Europe 1950-2015. Data aggregated from countries in different regions of Europe; (in \% of population)

Northern Europe Channel Islands, Denmark, Estonia, Finland, Iceland, Ireland, Latvia, Lithuania, Norway, Sweden, UK

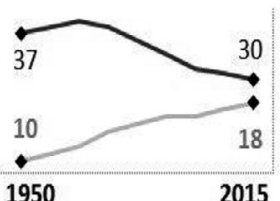

Ages 0-24

Ages 65+

$1950 \quad 2015$

Western Europe Austria, Belgium, France, Germany, Luxembourg, Netherlands, Switzerland

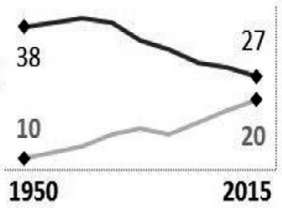

Ages 0-24

Ages 65+

1950

2015

Southern Europe Albania, Bosnia \& Herzegovina, Croatia, Greece, Italy, Malta, Macedonia, Montenegro, Portugal, Serbia, Slovenia, Spain

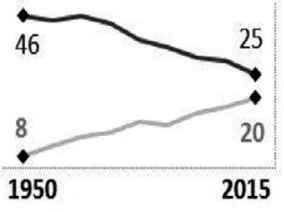

Ages 0-24

Ages 65+

\section{2015}

\section{Eastern Europe Belarus, Bulgaria, Czech Rep., Hungary, Moldova, Poland, Romania, Russia, Slovakia, Ukraine}

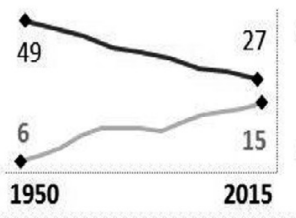

Ages 0-24 


\section{THE NEED FOR SKILLS, ADMINISTRATION AND AGE MANAGEMENT FOR MIGRANTS}

Integration should be seen as a long term and multi-factored process aimed at a situation where migrants are fully fledged members of the host society. The end effects may vary depending on factors such as age, gender, education and proximity to the host culture. These features should determine the preparation of effective programmes and integration mechanisms, also conditioning the time needed for those to succeed, taking into consideration profile of the migrant from outside of UE (figure 3) and age of asylum seeker (figure 4). Based on the data we can estimate that average newcomer to UE is young man.

Figure. 6.

Profile of migrants arriving in EuropeSource: data base on UNHCR database, 2015

Figure 7.

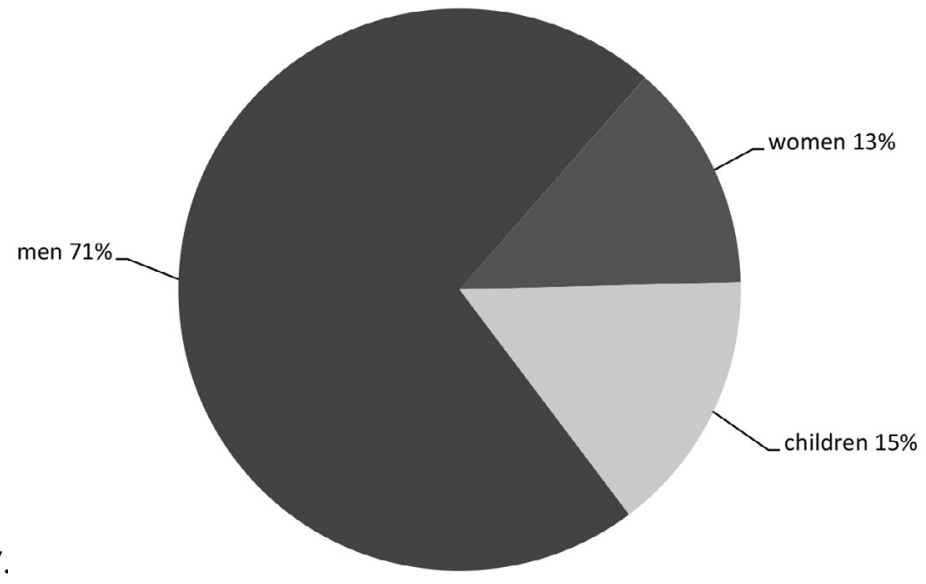

Average age of asylum seekers in EU

\begin{tabular}{|c|c|c|}
\hline Age group & \multicolumn{2}{|c|}{ Share of asylum seekers } \\
\hline $0-13$ & $18,1 \%$ & |||||||| \\
\hline $14-17$ & $8,3 \%$ & |||| \\
\hline $18-34$ & $55 \%$ & |||||||||||||||||||||||||| $\mid$ \\
\hline $35-64$ & $18 \%$ & |||||||| \\
\hline 65 or older & $0,6 \%$ & $\mid$ \\
\hline
\end{tabular}

Source: Eurostat (2015), based on 688.065 migrants from outside of UE. 
The challenges arising from the influx of migrants are not solely limited to logistics, but primarily with their integration, which should commence right after their arrival. The Integration is a two way process, thus changes affect both migrants and the host society. The influx of migrants poses a challenge to the state and its institutions, but also to society itself. It seeks systemic solutions, which entails budgetary spending. This is primarily accommodation for migrates, legalising their stay, and also starting their integration programmes. Pre-integration programmes encompass language courses and social and job orientation. Migrants should also be supported in their entry onto the labour market. In the case of highly skilled workers this means validating their diplomas and qualifications, and in the case of low skill workers - courses and training sessions, that answer to the needs of the labour market and raise the chance of obtaining a job. Voluntary migrants most often settle in large cities. This can be linked to the creation of ethnic ghettoes, which hampers the process of adaptation and assimilating the rules of the host country. The next issue is educating children, who should be incorporated into the local educational system, in order to avoid backlogs preferably with a teacher who speaks their language. Very often additional language courses are applied.

The host society also requires reinforcement of institutions as there is rise in uncertainty in human relations and lack of understanding. The influx of migrants is linked to rising $\mathrm{w}$ tensions in the society which has strong links to certain cultural and national identities, including the rise of racism and xenophobia. People are not easily accept other cultures. The influx of migrants is to part of the society linked with weaker national traditions, a destabilised public order that threatens the economic welfare of individuals, as migrants are seen as threats to the order of things. Thus their arrival also causes changes in the host society. Constructing correct relations with migrants requires formal and informal institutions that allow accepting otherness - people from other cultures, other nationalities, other religions. The experiences of Western European countries show that the effects of these programmes can only be seen in the second generation (Prokurat, Fabisiak, 2018).

The current situation calls for the management of migration, well beyond individual countries and societies. Undertaking topic of management of 
migration should be done in accordance with basic migration experience model. A migrant in his new place of stay undergoes a process of acculturation, according to J. Berry, which includes four options (Berry, 1992): first, the migrant retains his culture and accepts the host culture, resulting in 'adaptation'. Second, the migrant retains his culture and rejects the values of the host country, resulting in 'isolation'. Third, the migrant negates his culture and accepts the host culture, resulting in 'assimilation'. Four, the migrant negates his culture and that of the host country, resulting in 'marginalisation'. The second and fourth options are worse for functioning in the new society.

Figure 8.

Skills, Age and Agministration management policies required to be undertaken

\begin{tabular}{|c|l|}
\hline Integration area & \\
\hline \multicolumn{1}{c|}{ Skills } \\
management & $\begin{array}{l}\text { Actions taken } \\
\text { Educational policy for incoming migrants } \\
\text { Institutions that will enable job activation for migrants } \\
\text { Selecting migrant skills and creating migrant categories, depending on } \\
\text { their social utility. } \\
\text { Creating a database with skills needed on European market } \\
\text { Trainings on the local labour market }\end{array}$ \\
\hline Age management & $\begin{array}{l}\text { Evaluating the possibility of working given the experience and health of } \\
\text { the migrant } \\
\text { Evaluating work preferences according to: gender, age, experience. } \\
\text { Using age management tools for migrants }\end{array}$ \\
\hline Administration & $\begin{array}{l}\text { Administration of migration studies for the bureaucracy } \\
\text { Anti-discrimination policy on the labour and housing markets } \\
\text { Preventing the formation of ghettos } \\
\text { Institutions aimed at migrants (branches of migration offices, informa- } \\
\text { tion points and family help) } \\
\text { Information materials in the migrants' language } \\
\text { Personnel in the public institutions trained in helping migrants and } \\
\text { speaking their language } \\
\text { Loan institutions for migrants } \\
\text { Legal advice for migrants } \\
\text { Cultural training for migrants } \\
\text { Family unity policies }\end{array}$ \\
\hline
\end{tabular}

Source: author's compilation 


\section{EUROPEAN UNION MIGRATION MONITORING POLICIES AND ACTIONS}

First promigration actions have been undertaken by the $\mathrm{EU}$ in the early 1990s, when the Maastricht and Amsterdam treaties identified the concept of European citizenship, together with passages on the common visa policies and he aims of the Schengen area. The next important step were the recommendations from the Council of Europe summit in Tampere in 1999 (Oudenaren, 2005, p. 246). They touched on the common border policies and asylum policies as part of the creation of the „European area of freedom, safety and justice" (Molle, 2006, p. 105). At the same time relevant passages about cooperation with third parties on migration also appeared in European law-making. Currently the migration process and preventing illegal migration is carried out with tools that enable the EU to implement its goals. Two new systems stand out from these: the Visa Information System (VIS), containing information on visas granted and its exchange between member states; and the Schengen Information System (SIS and SIS II) that contains data on missing persons and objects (Balzacq, 2006). Both systems foresee the exchange of information between countries. Also in place is the European Border Monitoring System - Eurosur, whose aim is to seal EU borders, limit the numbers of illegal migrants, improving the security of EU states, by preventing drug, arms and human trafficking. Another institution tasked with these aims is Frontex (European Agency for the Management of Operational Cooperation at the External Borders of the Member States of the European Union) that works closely with the European Police Agency. According to European law external border countries are responsible for accepting, registering and processing applications from migrants and for their care until such time of their acceptance.

Up to now the common migration policy of the EU hast not had much success. The common policies passed required the least amount of changes possible from all member states. On the one hand this strategy allows for slow adaptation, on the other it does not allow to manage crises facing Europe since the start of the second decade of the $21^{\text {st }}$ century. A lack of complex and standardised procedures is not the only weakness of European migration policy. The other is a lack of external border security. It is essential 
to coordinate policy, which would enable the long-term prevention of illegal immigration and accepting the right people. There is ongoing discussion on EU policies that might be reffered as "European Programme for Migrations" and will undertake topics mentioned in this article ${ }^{1}$.

\section{CONCLUSION}

Europe requires a new, consistent and consequent policy on migration. This calls for the use of policies and practise already available including age management, skills and administration management for migrants. All agents must be involved: member states, EU institutions, international organisations, civic society, local governments and third countries should work together so that a common EU migration policy may come into being. The EU must work in a holistic way on strengthening external borders, efficiently differentiating between refugees and economic migrants, also unskilled and higly skilled newcomers. If Europe is not able to cope with the wave of migrants from the Middle East and Africa, it will run the risk of returning to internal border controls, with populists taking power and the successes of the EU project may be reverted. Individual member states have problems with population ageing and the looming entitlement reform (retirement funds, social systems) and so demographic change in the EU may, in the long run, hamper economic growth. Immigration can mitigate the impact of the demographic shift, particularly if migrants are mostly younger working-age people who are motivated to work. Some welfare arrangements in Europe noticeably need wide-ranging recalibration

\section{References}

Armbruster, H., Meinhof, U. (2011). Negotiating Multicultural Europe: Borders, Networks, Neighbourhoods, New York: Palgrave Macmillan. ISBN 9780230346475.

Balzacq, T. (2006). Security Versus Freedom?: A Challenge for Europe's Future, New York: Sergio Carrera. ISBN 9780754648321.

Berry, J. (1992). Cross-cultural Psychology: Research and applications, Cambridge: Cambridge University Press. ISBN 9780521745208.

Bongaarts, J. (2009). Human population growth and the demographic transition, "Philosophical Transactions B”, Oct 27; 364 (1532), p. 2985-2990. ISSN 1471-2970. 
Bonifazi, C., Okólski, M. (2008). International Migration in Europe: New Trends and New Methods of Analysis, Amsterdam Amsterdam University Press. ISBN 9789053568941.

Cesarani D., Fulbrook M., (2002). Citizenship, Nationality and Migration in Europe, London-New York: Routledge. ISBN 9780415131018.

Clemens, M. (2011). Economics and Emigration: Trillion-Dollar Bills on the Sidewalk?, "Journal of Economic Perspectives", Vol 25, No.3, Summer 2011, p. 83-106. ISSN 0895-3309.

Clemens, M. (2013). The Effect of Foreign Labor on Native Employment: A Job-Specific Approach and Application to North Carolina Farms, Center for Global Development Working Paper 326.Cohen, J., Sirkeci, I. (2011). Cultures of Migration: The Global Nature of Contemporary Mobility, Austin: University of Texas Press, p. 99. ISBN 9780292726857.

COM (2015), 240.

Council of Europe (2006). Achieving Social Cohesion in a Multicultural Europe, Strasbourg.

Database International Organization For Migration (www.iom.int), 2016.

Database: Eurostat, 2015

Database: OECD, 2015

Database: UNHCR, 2015

European Commission (2002). European Social Statistics, Demography, Luxembourg.

Halpern, D. (2010). The Hidden Wealth of Nations, Cambridge: Polity. ISBN 9780745648026.

Jones, R., Lopez K. (2006). Human Reproductive Biology, London: Academic Press. ISBN 9780123821843.

Kamusella, T. (2003). Polska państwem imigracyjnym?, w: Serwański J., Burszta W.J. (red.) Migracja - Europa - Polska, Poznań: Wydawnictwo Naukowe UAM. ISBN 8385376119.

Kasnitz, P., Mollenkopf, J., Holdaway, J., Waters, M. (2008). Inheriting the City: The Children of Immigrants Come of Age, New York: Russell Sage Foundation. ISBN 9780871544780 .

Lavenex, S., Uçarer, E. (2003). Migration and the Externalities of European Integration, Oxford: Lexington Books . ISBN 9780739106297. 
Lazaridis, G. (2016). Security, Insecurity and Migration in Europe, London: Routledge. ISBN 9781409409205.

Lee, E.S. (1966). A theory of migration, Demography, 3, p. 47-57. ISSN 0070-3370.

Mathers, C.D., Sadana, R., Salomon, J.A., Murray, C.J.L., Lopez, A.D. (2001). Healthy Life Expectancy in 191 Countries, 1999, Lancet, Vol. 357, pp. 1685-1691. ISSN 0140-6736.

Messina, A. (2007). The Logics and Politics of Post-WWII Migration to Western Europe, Cambridge: Cambridge University Press. ISBN 9780521821346.

Miles, R., Thränhardt, D. (1995). Migration and European Integration: The Dynamics of Inclusion and Exclusion, London: Fairleigh Dickinson Univ Pr. ISBN 9780838636138.

Molle, W. (2006). The Economics of European Integration: Theory, Practice, Policy, Burlington: Routledge. ISBN 9780754648123.

Nibbs, F., Brettell C. (2016). Identity and the Second Generation: How Children of Immigrants Find Their Space, Nashville: Vanderbilt University Press. ISBN 9780826520685 .

Oudenaren, J. (2005). Uniting Europe: An Introduction to the European Union, Oxford.

Pojmann, W. (2008). Migration and Activism in Europe since 1945, New York: Palgrave Macmillan US. ISBN 9780230615540.

Prokurat, S. (2010). European Social Model and East Asian Economic Model - different approach to productivity and competition in economy, w: Skulska, B. (ed.) "Asia - Europe. Partnership or Rivalry?”, Wrocław: Uniwersytet Ekonomiczny we Wrocławiu, p. 35-47. ISBN 9788376950075.

Prokurat, S. (2011). Wpływ Europejskiego Modelu Społecznego na wyrównywanie nierówności społecznych w Europie, „Nierówności Społeczne a Wzrost Gospodarczy”, 18, p. 150-162. ISSN 1898-5084.

Prokurat, S., Fabisiak, J. (2018). Current Demographic Trends Induced by Changing Fertility Patterns in Europe and the United States, "Studia Prawno-Ekonomiczne", 106, p. 295-317. ISSN 0081-6841.

Smith, A. (1954). Badania nad natura i przyczynami bogactwa narodów, t. 1, Warszawa: Państwowe Wydawnictwo Naukowe.

Spring Global Attitudes survey (2014).

Such-Pyrgiel, M. (2018). Nowe modele biznesu $w$ dobie transformacji cyfrowej $\mathrm{w}$ : Społeczne ekonomiczne aspekty zarzadzania $w$ organizacjach przyszłości, M. Sitek, M. Such-Pyrgiel (red.), s. 39-56. ISBN 9788362753956 
Tausch, A. (2008). Multicultural Europe, New York: Nova Science Publishers. ISBN 9781604568066.

Thränhardt, D. (1992). Europe, a New Immigration Continent: Policies and Politics in Comparative Perspective, Munster: Lit Verlag. ISBN 9783894733629.

UN World Population prospects (2015).

Yldız, A. (2016). The European Union's Immigration Policy: Managing Migration in Turkey and Morocco, London: Palgrave Macmillan UK. ISBN 9781137586988.

Zimmermann K. (2005). European Migration: What Do We Know?, Oxford: Oxford University Press. ISBN 9780199257355.

Zincone G., Penninx R., Borkert M. (2011). Migration Policymaking in Europe: The Dynamics of Actors and Contexts in Past and Present, Amsterdam: Amsterdam University Press. ISBN 9789089643704.

\section{Endnotes}

1 Data taken from: International Organization For Migration (www.iom.int), 2016.

2 Additionally, more information can be read in: Kasnitz P., Mollenkopf J., Holdaway J., Waters M. (2008), Inheriting the City: The Children of Immigrants Come of Age, New York; also: Nibbs F., Brettell C. (2016), Identity and the Second Generation: How Children of Immigrants Find Their Space, Nashville.

${ }^{3} \operatorname{COM}(2015), 240$. 